\title{
The light intensity in growth, behavior and skin pigmentation of juvenile catfish Lophiosilurus alexandri (Steindachner)
}

\author{
Thaís G. Santos ${ }^{1}$, Marianne Schorer ${ }^{1}$, José C.E. dos Santos $^{2}$, Afonso Pelli ${ }^{3}$ \& Marcelo M. Pedreira $^{1}$ \\ ${ }^{1}$ Laboratory of Aquaculture and Aquatic Ecology, Federal University of the Jequitinhonha and Mucuri Valleys \\ Diamantina, Minas Gerais, Brazil \\ ${ }^{2}$ Development Company of the São Francisco and Parnaíba, Hydrobiology and Fish Culture \\ Station of Três Marias, Três Marias, Minas Gerais, Brazil \\ ${ }^{3}$ Department of Pathology, Genetics, and Evolution, Federal University of Triângulo Mineiro \\ Uberaba, Minas Gerais, Brazil \\ Corresponding author: Marianne Schorer (marianne.schorer@gmail.com)
}

\begin{abstract}
The survival of several fish species in captivity depends on their adaptation to the environmental conditions and the biological characteristics. The objective of the study was to evaluate the influence of different light intensity levels in growth, behavior and skin pigmentation in juvenile of Lophiosilurus alexandri. Fishes were exposed to the following luminosities: 0, 218, 278, and 459 lux. The experiment was conducted for 75 days, in a water recirculation system with controlled temperatures and aeration. Catfish juvenile were distributed in $35 \mathrm{~L}$ aquariums, at the density of 0.28 ind $\mathrm{L}^{-1}$. In order to evaluate fish growth, weight, standardtotal length, weight gain, food consumption, food conversion, biomass, specific growth rate and survival were measured twice times a month. Also, swimming behavior, skin pigmentation and plasma cortisol levels were evaluated. Light influences L. alexandri feed consumption, food conversion, behavior and plasma cortisol levels. Environments with low light are recommended for the L. alexandri growth.
\end{abstract}

Keywords: bottomfish; environment luminosity; fish activity; light incidence; aquaculture

\section{INTRODUCTION}

The catfish Lophiosilurus alexandri (Steindachner, 1876), also popularly known as pacamã, has great importance for fishing and aquaculture, and is much appreciated by consumers due to its meat taste and fillet quality, which is free of intramuscular spines (Marques et al., 2008). This carnivorous neotropical freshwater fish is endemic to South America, has easy eggs and larvae propagation in the laboratory, besides great rusticity and acceptance of commercial feed (Barros et al., 2007; Guimarães-Cruz et al., 2009).

Researches in the juvenile phase of $L$. alexandri are required to manage systems adaptation, and to maximize seed production. Therefore, the information of how the intensity of light can influence the growth and physiology of these species during the juvenile phase has been explored, bringing new information of this catfish culture (Pedreira et al., 2012; Kitagawa et al., 2015).

Catfish have different luminous preferences, and it can directly influence its growth, survival, skin pigmentation, behavior and seed quality (Brito \& Pienaar, 1992; Bouef \& Bail, 1999; Almazán-Rueda et al., 2004; Ginés et al., 2004; Fatollahi \& Kasumyan, 2006; Pedreira et al., 2012; Costa et al., 2016). Seeking more information in the literature, some fish may have changes in their color, behavior and physiology, depending on the environment they inhabit, commonly to protect themselves from predators or to demarcate territory (Mizusawa et al., 2011).

Receptivity of fish to brightness in environments may change according to their stage of development (Boeuf \& Le Bail, 1999), and as already known the absence of light increase catfish larvae growth (Brito \& Pienaar, 1992; Han et al., 2005; Kitagawa et al., 2015).

Corresponding editor: Alejandra Volpedo 
In daily cleaning, some care should be taken, since the behavior of this species is to remain in the bottom of the aquarium, defaulting its visualization. The ideal level of light intensity may determine better fish performance, without causing stress.

Thus, the objectives of this study were to evaluate the influence of different light intensities on growth, behavior and skin pigmentation of Lophiosilurus alexandri juvenile.

\section{MATERIALS AND METHODS}

The experiment was conducted at the Aquaculture and Aquatic Ecology Laboratory of the Federal University of the Jequitinhonha and Mucuri Valleys, in Diamantina, Minas Gerais (1387 m a.s.1.; 18¹0'S, $43^{\circ} 30^{\prime} \mathrm{W}$ ), and the duration of the study was 75 days. The work was conducted following the ethical standards and approved by the Ethics Committee on the Use of Animals (Process Nº50/2015).

One hundred and sixty pacamã Lophiosilurus alexandri juvenile, with a mean weight of $5.4 \pm 1.09 \mathrm{~g}$ (mean $\pm \mathrm{SD}$, standard deviation), the standard length (SL) of $6.3 \pm 0.52 \mathrm{~mm}$ and the total length (TL) of 7.5 $\pm 0.57 \mathrm{~mm}$, were used. The juveniles were distributed in 16 aquariums, with a white background, at the stocking density of 10 juveniles per aquarium $(0.28$ ind $\mathrm{L}^{-1)}$, with a useful volume of $35 \mathrm{~L}$, in a water recirculation system with an average temperature of $28.0 \pm 1.0^{\circ} \mathrm{C}$. The aeration was constant, and the photoperiod was $12 \mathrm{~h}$ of light and $12 \mathrm{~h}$ of darkness (12L: 12D), controlled by a Fox lux digital timer.

The water parameters were measured one day a week in the morning, before the first feeding, using a multiparameter probe Horiba U-22 XD: temperature $\left({ }^{\circ} \mathrm{C}\right)$, dissolved oxygen $\left(\mathrm{mg} \mathrm{L}^{-1}\right), \mathrm{pH}$ and electrical conductivity of water $\left.(\mu \mathrm{S} \mathrm{cm})^{-1}\right)$ were scanned. The concentrations of ammonia $\left(\mathrm{mg} \mathrm{L}^{-1}\right)$, nitrite $\left(\mathrm{mg} \mathrm{L}^{-1}\right)$ and nitrate $\left(\mathrm{mg} \mathrm{L}^{-1}\right)$ were determined according to the methodology APHA (2012). The water quality parameter were: $27.9 \pm 2.34^{\circ} \mathrm{C}$ for temperature; $6.0 \pm$ $0.55 \mathrm{mg} \mathrm{L}^{-1}$ for dissolved oxygen; $6.7 \pm 0.18$ for $\mathrm{pH}$; $60.2 \pm 2.25 \mu \mathrm{S} \mathrm{cm}^{-1}$ for conductivity; $0.04 \pm 0.03 \mathrm{mg} \mathrm{L}^{-1}$ for total ammonia; $0.02 \pm 0.02 \mathrm{mg} \mathrm{L}^{-1}$ for nitrite and 1.6 $\pm 0.47 \mathrm{mg} \mathrm{L}^{-1}$ for nitrate.

Every week, the intensity of light was measured within the laboratory environment, using a digital model LD-209, which was positioned $30 \mathrm{~cm}$ above all aquaria, presenting an average intensity of light of $952.0 \pm 29.50$ lux. The treatment consisted of four levels of incidence of light in the aquariums: $0,218,278$, and 459 lux. The treatment without light intensity ( 0 lux) was planned with no light input, and black canvas covered the aquarium overall. Treatment with the intensity of light of 218 and 278 lux, were covered with $70 \%$ and $50 \%$ mesh shading, respectively. Lastly, the intensity of light of 459 lux, 100\% light intensity, was obtained maintaining the aquariums without cover. The black canvas and mesh shading for cover the aquariums are easily found in agricultural and livestock stores and have low cost, so were chosen for use in the experiment.

Every week, the intensity of light of the aquariums (lux) were measured in the morning, with a digital luximeter model LD-209 Instrutherm, above the water surface of each aquarium, the mean values and deviations were: $0.0 \pm 0.00 ; 218.5 \pm 13.01 ; 277.9 \pm$ 15.84 and $458.6 \pm 22.48$ lux. Covered aquariums had their incidence of light measured under the black canvas and mesh shading. The experimental design was completely randomized with four treatments and four replications each.

Catfish juveniles were fed with commercial feed, composed with crude protein ( $\mathrm{min}) 360 \mathrm{~g} \mathrm{~kg}^{-1}$, ethereal extract (min) $50 \mathrm{~g} \mathrm{~kg}^{-1}$, fibrous matter (max.) $70 \mathrm{~g} \mathrm{~kg}^{-1}$ and mineral matter (max.) $120 \mathrm{~g} \mathrm{~kg}^{-1}$, daily at 8:00 and 17:00 h, until apparent satiation.

In order to measure the growth parameters of fish, twice a month all fishes were anesthetized with Eugenol solution dissolved in water. This solution was prepared in the dosage of $5.0 \mathrm{~mL}$ of Eugenol solution mixed to $95 \mathrm{~mL}$ of absolute alcohol, and $1 \mathrm{~mL}$ of this solution was added to each liter of water (PaivaRanzani, 2013). To obtain the body weight, a Mars analytical balance, with an accuracy of $0.01 \mathrm{~g}$, and the standard total length was obtained with an EDA digital caliper, with an accuracy of $0.01 \mathrm{~mm}$.

It was still evaluated: body weight $(\mathrm{g})$, standard length $(\mathrm{cm})$, total length $(\mathrm{cm})$, biomass $(\mathrm{g})$ and survival (\%). According to the records of total food consumption and weight gain $(\mathrm{g})=$ (final mean weight - initial mean weight); specific growth rate $(\mathrm{SGR})=(\ln$ (final body weight) $-\ln ($ initial body weight) $) /$ days $\times 100$; and food conversion $(\mathrm{CA})=\left(\right.$ food consumption $\times$ weight gain $\left.^{-1}\right)$.

Swimming behavior of the fishes was recorded by direct observation. These observations were performed weekly, in the morning, before daily feeding. All aquariums were observed for $2 \mathrm{~min}$, using a Vollo digital chronometer. The swimming behavior of the $L$. alexandri juveniles were evaluated and classified into three categories: sedentary group (when all juvenile were at rest at the bottom of the aquarium); partially sedentary group (when part of juvenile remained at rest at the bottom of the aquarium, and another part in swimming activity); and dispersed (when all remaining juvenile were in constant movement along the aquarium). 
At the end of the experiment, 20 juveniles of each treatment were previously anesthetized with Eugenol solution, at a dosage of $1 \mathrm{~mL} \mathrm{~L}^{-1}$, and three different points of the catfish body were measured using a Minolta CR400 colorimeter. The three chosen body parts were: upper central part of the head; the base of the dorsal fin on the left side; and at the top of the tail. For analysis of skin pigmentation the skin colors were quantified according to the CIE $\mathrm{L}^{*}$, $\mathrm{a}^{*}$ and $\mathrm{b}^{*}$ (coordinates Huntellab CIELab), where L* represents the luminosity or incidence of light (black $=0$, white $=$ $100) ; a^{*}$ measures the red-green dimension with positive values for redness and negative for green; and $\mathrm{b}$ *represents the yellow-blue dimension with positive values for yellow and negative for blue. The chromaticity values of $\mathrm{a}^{*}$ and $\mathrm{b}^{*}$ were transformed into specific chromatic attributes for calculating the color saturation, which is called chroma $\left(\mathrm{C}^{*}\right.$ ab $)$. The equation used for this transformation was: $\mathrm{C}^{*} \mathrm{ab}=\left(\mathrm{a}^{* 2}+\mathrm{b}^{* 2}\right)^{0.5}$.

For the analysis of blood plasma cortisol, five juvenile aquarium $^{-1}\left(20\right.$ treatment $\left.^{-1}\right)$, at the end of the experiment, were randomly selected. $400 \mu \mathrm{L}$ of blood was collected from each by caudal puncture, towards the ventral region of the spine, where the artery and caudal vein are located, with the aid of a syringe with a needle bathed in anticoagulant (EDTA 3\%). The blood was conditioned in Eppendorf, and refrigerated at $12^{\circ} \mathrm{C}$, and immediately after collection of all samples they were centrifuged at 1,000 rpm for $5 \mathrm{~min}$ and 3,000 rpm for another $5 \mathrm{~min}$ to collect the supernatant plasma with a micropipette. Plasma was refrigerated at $-80^{\circ} \mathrm{C}$ for further cortisol analysis in duplicates, which was determined with a commercially available ELISA kit (Enzyme-linked immunosorbent assay kit-Monobind $\left.\operatorname{Inc}^{\circledR}\right)$.

The evaluation of light incidence levels effects on performance, skin pigmentation and cortisol levels were performed by ANOVA and regression, at 0.05 of significance in the statistical program SAS 9.1. Survival values were transformed into a sine arc, for statistical analysis, but the values observed in percentages were presented in the tables. For the behavior data, a Chi-square test $\left(\chi^{2}\right)$ at 0.01 of significance was performed in the statistical program $\mathrm{R}$.

\section{RESULTS}

The parameters of body weight, weight gain, standardtotal length, biomass, specific growth rate and survival of catfish Lophiosilurus alexandri, were not influenced $(P>0.05)$ by the light incidence levels among treatments (Table 1).
The fish food consumption had a polynomial effect $(P<0.05)$, reaching the best level of food consumption with 253.53 lux. The food conversion enhanced linearly $(P<0.05)$ with the increase of the incidence of light in the aquaria. Aquariums without light (0 lux), there was a $34 \%$ reduction in food conversion compared to uncovered aquariums (459 lux).

The behavior of $L$. alexandri juvenile had interaction $(P<0.01)$ among the light incidence levels in the aquariums (Table 2$)$. There was a prevalence ( $P$ $<0.01$ ) of dispersal behavior in fish subjected to treatment without the incidence of light (0 lux). In the treatments with an intermediate incidence of light (218 and 278 lux), partially sedentary group behavior was predominant $(P<0.01)$. However, treatment without coverage (459 lux) the juvenile had a sedentary group behavior $(P<0.01)$.

The pacamã skin pigmentation was not influenced $(P<0.05)$ by the incidence of light (Table 3$). L$. alexandri plasma cortisol had a quadratic effect, and after derivation of the equation, a high level of this hormone was found in the incidence of light of 99.23 lux (Table 4).

\section{DISCUSSION}

The different incidence light levels ( 0 and 458 lux) did not influence Lophiosilurus alexandri juvenile growth, which can be related to the plasticity of the species in order to adapt to environmental variations and its circadian cycle due to the instability of their environments (Vera et al., 2009). Light intensity may be a limiting factor in fish farming, and different responses in diverse species and different developmental stages are reported (Boeuf \& Le Bail, 1999). However, most fish require a minimal light intensity to be able to grow normally (Han et al., 2005).

The need for luminous environments for catfish species varies according to the fish's stage of life, being species-specific (Stefansson et al., 1993). For the catfish Rhamdia quelen (Quoy \& Gaimard, 1824) development, dark environments (1.2 lux) are recommended (Behr et al., 1999). The African catfish Clarias gariepinus (Burchell, 1822) larvae have escape behavior as the light incidence increases, being interpreted as an adaptation to avoid predators that depend on the vision to detect prey (Brito \& Pienaar, 1992). The Chinese longsnout catfish Leiocassis longirostris (Günther, 1864), has its growth rate significantly reduced at lower or higher light intensities, while light intensity did not affect the survival (Han et al., 2005). 
Table 1. Mean values ( \pm SD) of the performance of Lophiosilurus alexandri juvenile submitted to different light intensity levels. *Quadratic effect $(P<0.05): \mathrm{y}=12.252+0.0199 \mathrm{x}-0.7007 \times 2 ; \mathrm{R}^{2}=0.77 .{ }^{* *}$ Linear effect $(P<0.05): \mathrm{y}=1.0059$ $+0.049 \mathrm{x} ; \mathrm{R}^{2}=0.92$. $\mathrm{CV}$ : coefficient of variation.

\begin{tabular}{lrrrrr}
\hline Parameters & \multicolumn{1}{c}{0 lux } & \multicolumn{1}{c}{218 lux } & \multicolumn{1}{c}{278 lux } & \multicolumn{1}{c}{459 lux } & \multicolumn{1}{c}{ CV (\%) } \\
\hline Final weight (g) & $18.45 \pm 4.54$ & $18.65 \pm 6.38$ & $18.13 \pm 6.11$ & $17.73 \pm 5.88$ & $17.73 \pm 5.88$ \\
Weight gain (g) & $12.91 \pm 4.76$ & $13.16 \pm 6.43$ & $12.30 \pm 5.82$ & $11.51 \pm 5.75$ & $11.51 \pm 5.75$ \\
Standard length (cm) & $9.36 \pm 0.85$ & $9.49 \pm 1.11$ & $9.36 \pm 1.07$ & $9.17 \pm 1.06$ & $9.17 \pm 1.06$ \\
Total length (g) & $11.02 \pm 0.94$ & $11.15 \pm 1.32$ & $10.96 \pm 1.16$ & $10.78 \pm 1.28$ & $10.78 \pm 1.28$ \\
Feed consumption (g) ${ }^{*}$ & $124.00 \pm 5.87$ & $142.7 \pm 4.20$ & $175.1 \pm 9.50$ & $167.0 \pm 12.21$ & $167.0 \pm 12.21$ \\
Food conversion (g g) ${ }^{* *}$ & $0.96 \pm 0.25$ & $1.16 \pm 0.34$ & $1.33 \pm 0.10$ & $1.45 \pm 0.37$ & $1.45 \pm 0.37$ \\
Biomass (g) & $184.50 \pm 2.51$ & $186.50 \pm 1.71$ & $181.30 \pm 1.70$ & $177.30 \pm 3.76$ & $177.30 \pm 3.76$ \\
Specific growth rate (\%) & $17.37 \pm 6.38$ & $17.65 \pm 8.67$ & $16.91 \pm 7.65$ & $16.24 \pm 7.66$ & $16.24 \pm 7.66$ \\
Survival (\%) & $100.00 \pm 0.00$ & $100.00 \pm 0.00$ & $100.00 \pm 0.00$ & $100.00 \pm 0.00$ & $100.00 \pm 0.00$ \\
\hline
\end{tabular}

Table 2. Absolute frequency of swimming behavior of Lophiosilurus alexandri juvenile submitted to different light intensity levels. Value of the Chi-square $\left(\chi^{2}\right): 70.44$. *Statistically significant at 0.01 .

\begin{tabular}{lcrrrr}
\hline \multirow{2}{*}{ Behavior } & \multicolumn{5}{c}{ Light intensity (lux) } \\
\cline { 2 - 6 } & 0 & 218 & 278 & 459 & Total \\
\hline Sedentary group* & 7 & 11 & 10 & 28 & 56 \\
Partially sedentary group* & 6 & 24 & 26 & 10 & 66 \\
Dispersed* $^{30}$ & 8 & 8 & 5 & 50 \\
\hline Total & 43 & 43 & 43 & 43 & 172 \\
\hline
\end{tabular}

The low incidence of light decreases the feed consumption of $L$. alexandri, and according to the literature, the regulation of physiological mechanisms may interfere in the fish intake and efficiency (Boeuf \& Le Bail, 1999). For the catfish, Wallago attu (Bleeker, 1851), the low incidence of light also decreased food consumption (Giri et al., 2002). Similarly, feed consumption of Clarias gariepinus catfish increased with increasing light intensity, over time, indicating that the species can detect food in the absence of light; this occurs because a mechanism (barbels) that are very sensitive in detecting any material that enters your environment (Jauro \& Usman, 2015), as L. alexandri (Assega et al., 2016).

The food conversion of the catfish juvenile raised with the increased light incidence. This increase in food conversion may be related to the feeding habits of the bottom species, which take advantage of food in dark environments since this condition resembles its natural habitat (Veras et al., 2013). Pedreira et al. (2012) described that dark environments are suitable for larviculture success of $L$. alexandri species with a benthic habit, also observed in other catfish (Jauro \& Usman, 2015; Assega et al., 2016).

The light intensity influenced the swimming activity of $L$. alexandri juvenile, and treatment without light (0 lux) have a superior swimming activity registered. Similar results were reported for nocturnal behavioral species, as the African catfish and the Anguilla anguilla (Linnaeus, 1758), which has better food conversion in dark environments (Rodriguez et al., 2009; Mustapha et al., 2012). In contrast, the Colossoma macropomum (Cuvier, 1816), a diurnal habit species, the light incidence improves food conversion (Mendonça et al., 2009).

Regarding the swimming activity behavior of $L$. alexandri juvenile without light, the African catfish and the haddock Melanogrammus aeglefinus (Linnaeus, 1758) also demonstrate this pattern of behavior (Trippel \& Neil, 2003; Mustapha et al., 2012). Also, the environmental factors, such as light season, influence the fish's biological cycle (Fálcon et al., 2010). Almazan-Rueda et al. (2004) observed that light intensity seems to strongly affect the aggressive behavior of African catfish, having more stressed fish in brighter environments.

The incidence of light did not influence the skin pigmentation parameters of $L$. alexandri, either on the central part of the head, the base of the dorsal fin, or at the top of the tail, with values of $\mathrm{L}^{*}$ among 44 and 53, suggesting a plastic adaptation capacity of the species inhabits the environment. For other catfish species, the plasticity of adaptation was observed in Leiocassis longirostris (Bleeker, 1864) juvenile and Australian Pagrus auratus (Forster, 1801) juvenile, which has darker skin pigmentation (lower values of $\mathrm{L}^{*}$ ) under high light intensity (434 lux) (Booth et al., 2004, Han et al., 2005).

The light incidence did not influence changes in the skin color tone $\left(\mathrm{H}^{\circ} \mathrm{ab}\right)$, intensity parameters $\left(\mathrm{C}^{*} \mathrm{ab}\right)$ and in the whiteness of color $\left(\mathrm{W}^{*}\right)$ in fishes. For catfish $L$. longirostris, when exposed to luminosities above 400 lux, it had a higher intensity of color and less whiteness of the skin (Han et al., 2005). According to these authors, 
Table 3. Mean values $( \pm \mathrm{SD})$ of $\mathrm{a}^{*}, \mathrm{~b}^{*}$ and $\mathrm{L}^{*}$ (luminosity), $\mathrm{C}^{*}$ ab (Chroma), Hab (tone) and $\mathrm{W}^{*}$ (whiteness) of the skin pigmentation of Lophiosilurus alexandri juvenile submitted to different levels of light intensity levels. CV: coefficient of variation. *Statistically significant at 0.05 .

\begin{tabular}{|c|c|c|c|c|c|}
\hline \multirow{2}{*}{ Parameters } & \multicolumn{4}{|c|}{ Light intensity (lux) } & \multirow{2}{*}{$\begin{array}{l}\text { CV } \\
(\%)\end{array}$} \\
\hline & 0 & 218 & 278 & 459 & \\
\hline \multicolumn{6}{|l|}{ Head } \\
\hline$a^{*}$ & $4.24 \pm 2.23$ & $3.39 \pm 0.64$ & $3.33 \pm 0.64$ & $4.24 \pm 0.71$ & 11.39 \\
\hline$b^{*}$ & $7.23 \pm 2.97$ & $6.93 \pm 2.14$ & $6.90 \pm 2.11$ & $7.23 \pm 2.18$ & 6.64 \\
\hline $\mathrm{L}^{*}$ & $45.11 \pm 6.47$ & $47.08 \pm 1.76$ & $46.02 \pm 1.64$ & $45.11 \pm 1.69$ & 1.75 \\
\hline $\mathrm{C}^{*} \mathrm{ab}$ & $8.58 \pm 3.21$ & $7.55 \pm 1.84$ & $7.75 \pm 1.90$ & $7.38 \pm 1.78$ & 6.83 \\
\hline $\mathrm{H}_{\mathrm{ab}}^{\mathrm{o}}$ & $1.02 \pm 0.19$ & $1.06 \pm 0.19$ & $1.08 \pm 0.15$ & $0.99 \pm 0.25$ & 11.62 \\
\hline $\mathrm{W}^{*} \mathrm{ab}$ & $45.21 \pm 1.52$ & $46.67 \pm 1.65$ & $45.44 \pm 1.67$ & $44.38 \pm 6.88$ & 1.4 \\
\hline \multicolumn{6}{|l|}{ Dorsal } \\
\hline $\begin{array}{l}a^{*} \\
b^{*}\end{array}$ & & $\begin{array}{r}1.24 \pm 0.88 \\
1127+3.55\end{array}$ & & & $\begin{array}{r}16.99 \\
7.53\end{array}$ \\
\hline $\begin{array}{l}b^{*} \\
I^{*}\end{array}$ & $11.63 \pm 3.48$ & $\begin{array}{l}11.27 \pm 3.55 \\
5351+301\end{array}$ & $\begin{array}{l}10.19 \pm \\
5245+\end{array}$ & $\begin{array}{l}11.63 \pm 3.53 \\
52.29+3.07\end{array}$ & $\begin{array}{l}7.53 \\
1.11\end{array}$ \\
\hline $\mathrm{L}^{*}$ & $52.29 \pm 3.49$ & $53.51 \pm 3.01$ & $52.45 \pm$ & $32.29 \pm 3.01$ & \\
\hline $\mathrm{C}^{*} \mathrm{ab}$ & $11.94 \pm 3.21$ & $11.15 \pm 3.79$ & $10.35 \pm 3.22$ & $11.88 \pm 3.44$ & 8.06 \\
\hline $\mathrm{H}_{\mathrm{ab}}^{\mathrm{o}}$ & $1.33 \pm 0.20$ & $1.40 \pm 0.09$ & $1.43 \pm 0.13$ & $1.86 \pm 0.10$ & 16.18 \\
\hline $\mathrm{W}^{*} \mathrm{ab}$ & $51.29 \pm 2.49$ & $51.94 \pm 2.67$ & $51.23 \pm 3.21$ & $50.72 \pm 3.12$ & 0.98 \\
\hline \multicolumn{6}{|l|}{ Tail } \\
\hline$a^{*}$ & $2.04 \pm 0.66$ & $1.94 \pm 0.93$ & 2.73 & $2.34=$ & 15.69 \\
\hline$b^{*}$ & $8.76 \pm 3.15$ & $8.76 \pm 3.37$ & $8.88 \pm 3.31$ & $8.56 \pm 3.32$ & 6.37 \\
\hline $\mathrm{L}^{*}$ & $45.04 \pm 2.20$ & $45.53 \pm 2.19$ & $44.12 \pm 2.31$ & $45.04 \pm 2.36$ & 1.61 \\
\hline $\mathrm{C}^{*} \mathrm{ab}$ & $10.25 \pm 3.13$ & $8.77 \pm 3.05$ & $9.50 \pm 3.57$ & $8.95 \pm 3.01$ & 7.1 \\
\hline $\mathrm{H}_{\mathrm{a}}^{\mathrm{o}}$ & $1.50 \pm 0.03$ & $1.49 \pm 0.06$ & $1.44 \pm 0.23$ & $1.48 \pm 0.19$ & 15.35 \\
\hline $\mathrm{W}_{\mathrm{ab}}$ & $44.41 \pm 2.14$ & $45.02 \pm 2.10$ & $43.21 \pm 2.25$ & $44.24 \pm 2.05$ & 1.7 \\
\hline
\end{tabular}

Table 4. Mean values of cortisol in Lophiosilurus alexandri juvenile submitted to different light intensity levels. CV: coefficient of variation. *Quadratic effect $(P<0.05): \mathrm{y}=3.1419-0.0051 \mathrm{x}+0.3333 \mathrm{x} 2 ; \mathrm{R}^{2}=0.99$.

\begin{tabular}{lccccc}
\hline \multirow{2}{*}{ Parameter } & \multicolumn{4}{c}{ Light intensity (lux) } & CV \\
\cline { 2 - 5 } & 0 & 218 & 278 & 459 & $(\%)$ \\
\hline Cortisol $\left(\mathrm{ng} \mathrm{mL}^{-1}\right)^{*}$ & $3.14 \pm 1.06$ & $2.49 \pm 0.85$ & $2.43 \pm 0.89$ & $2.78 \pm 0.81$ & 11.99 \\
\hline
\end{tabular}

many teleosts can adjust the color of its skin in response to changes of the environment light incidence, and changes in the pigmentation occur by the alteration of the number of chromatophores and the mobilization of its pigments (Van Der Salm et al., 2006).

These changes in the skin pigmentation of $L$. alexandri were reported in juvenile of the same species (Costa et al., 2016), which in dark environments the skin darkening may occur two ways, the increasing of melanophores cell numbers, and by the increasing size of the melanophores in the pigments of the skin. However, these changes are not always predictable and may depend on several factors such as the stage of development, the light intensity of the environment and the number of chromatophores of the species (Fujii, 2000).

The L. alexandri juvenile had alterations in the plasma cortisol concentration, mainly in treatment without light (0 lux), which presented average values of
$3.14 \mathrm{ng} \mathrm{mL}^{-1}$. In continuous stress situation the harmful physiological responses, such as suppression of growth are described (Pickering, 1993; Barton, 2002), however, in the treatment with higher levels of cortisol, the juvenile had lower food consumption, better food conversion, and greater swimming activity.

Our cortisol dada values baseline ranged from 1.39 to $5.0 \mathrm{ng} \mathrm{mL}^{-1}$ for L. alexandri juvenile, and performing the polynomial regression, it was observed that the best point of light incidence, causing lower concentrations of cortisol, occurs among 278 and 459 lux, more concisely with 324 lux. Costa et al. (2016) observed the elevation of cortisol in $L$. alexandri juvenile when grown in dark environments, confirming the results with the species.

In other species of catfish, the basal concentration of cortisol vary widely; the channel catfish Ictalurus punctatus (Rafinesque, 1818) remained in the range of 4.0 to $50.0 \mathrm{ng} \mathrm{mL}^{-1}$; the surubim, Pseudoplatystoma 
corruscans (Spix \& Agassiz, 1829) between 3.4 and $18.3 \mathrm{ng} \mathrm{mL}^{-1}$; and for jundiá, Rhamdia quelen, the plasma levels were among 16.0 and $30.0 \mathrm{ng} \mathrm{mL}^{-1}$ (Barton \& Iwana, 1991; Barcellos et al., 2001; Lima \& Ribeiro, 2006; Fagundes \& Urbinati, 2008; Baßmann et al., 2017). Thus, the plasma cortisol concentrations observed in the experiment were at basal levels for the species and that after a long experimental period the fish were adapted to daily management.

In conclusion, the light influenced feed consumption, food conversion, behavior, and plasma cortisol levels. However, low light environments improve food conversion, which is a desirable feature of $L$. alexandri production.

\section{ACKNOWLEDGMENTS}

To the Foundation for Research Support of the State of Minas Gerais (FAPEMIG) and the Banco do Nordeste do Brasil for financial support; the Higher Education Personnel Improvement Coordination (CAPES), for granting the scholarship; the São Francisco and Parnaíba Valley Development Company (CODEVASF); and the National Council for Scientific and Technological Development (CNPq).

\section{REFERENCES}

Almazán-Rueda, P., Schrama, J.W. \& Verreth, J.A.J. 2004. Behavioral responses under different feeding methods and light regimes of the African catfish (Clarias gariepinus) juveniles. Aquaculture, 231: 347-359. doi: 10.1016/j.aquaculture.2003.11.016

American Public Health Association (APHA). 2012. Standard methods for the examination of water and wastewater. American Public Health Association, Washington.

Assega, F.M., Birindelli, J.L.O., Bialetzki, A. \& Shibatta, O.A. 2016. External morphology of Lophiosilurus alexandri Steindachner, 1876 during the early stages of development, and its implications for the evolution of Pseudopimelodidae (Siluriformes). Plos One, 11(4): 1-20. doi: 10.1371/journal.pone. 0153123

Barcellos, L.J.G., Woehl, V.M., Warssemann, G.F., Quevedo, R.M., Ittzes, I. \& Krieger, M.H. 2001. Plasma levels of cortisol and glucose in response to capture and tank transference in Rhamdia quelen (Quoi \& Gaimard), a South American catfish. Aquaculture Research, 32: 121-123.

Barros, M.D.M., Guimarães-Cruz, R.J., Veloso-Júnior, V.C. \& Santos, J.E. 2007. Reproductive apparatus and gametogenesis of Lophiosilurus alexandri Steinda- chner (Pisces, Teleostei, Siluriformes). Revista Brasileira de Zoologia, 24: 213-221. doi: 10.1590/ S0101-81752007000100028

Barton, B.A. \& Iwana, G.K. 1991. Physiological changes in fish from stress in Aquaculture with emphasis on the response and effects of corticosteroids. Annual Review of Fish Diseases, 1: 3-26.

Barton, B.A., 2002, Stress in fishes: a diversity of responses with particular reference to changes in circulating corticosteroids. Integrative and Comparative Biology, 42: 517-525.

Baßmann, B., Brenner, M. \& Palm, H.W. 2017. Stress and welfare of African catfish (Clarias gariepinus Burchell, 1822) in a coupled aquaponic system. Water, 9: 2-19.

Behr, E.R., Radünz-Neto, J., Tronco, A.P. \& Fontana, A.P. 1999. Influence of different levels of luminosity on the performance of jundiá larvae (Rhamdia quelen) (Quoy \& Gaimard, 1824) (Pisces: Pimelodidae). Acta Scientiarum, 21: 325-330.

Boeuf, G. \& Le Bail, P.Y.L. 1999. Does light have an influence on fish growth? Aquaculture, 177: 129-152.

Booth, M.A., Warner-Smith, R.J., Allan, G.L. \& Glencross, B.D. 2004. Effects of dietary astaxanthin source and light manipulation on the skin color of Australian snapper Pagrus auratus (Bloch \& Schneider, 1801). Aquaculture Research, 35: 458-464.

Brito, P.J. \& Pienaar, A.G. 1992. Laboratory experiments on the effect of light and cover on the behavior and growth of African catfish, Clarias gariepinus (Pisces: Clariidae). Journal of Zoology, 227: 43-62.

Costa, D.C., Mattioli, C.C. \& Silva, W.S. 2016. The effect of environmental color on the growth, metabolism, physiology and skin pigmentation of the carnivorous freshwater catfish Lophiosilurus alexandri. Journal of Fish Biology, 90: 922-935.

Fagundes, M. \& Urbinati, E.C. 2008. Stress in pintado (Pseudoplatystoma corruscans) during farming procedures. Aquaculture, 276(1-4): 112-119.

Fálcon, J., Migaud, H. \& Carrilo, M. 2010. Current knowledge on the melatonin system in teleost fish. General and Comparative Endocrinology, 165: 469482.

Fatollahi, M. \& Kasumyan, A.O.J. 2006. The study of sensory bases of the feeding behavior of the African catfish Clarias gariepinus (Clariidae, Siluriformes). Journal of Ichthyology, 46: 161-172.

Fujii, R. 2000. The regulation of motile activity in fish chromatophores. Pigment Cell Research, 13: 300-319.

Ginés, R., Afonso, J.M., Arguello, A., Zamorano, M.J. \& López, J.L. 2004. The effects of long-day photoperiod on growth, body composition and skin color in 
immature gilthead sea bream (Sparus aurata L.). Aquaculture Research, 35: 207-1212.

Giri, S.S., Sahoo, S.K., Sahu, B.B., Sahu, A.K., Mohanty, S.N. \& Ayyappan, S. 2002. Larval survival and growth in Wallago attu (Bloch and Schneider): effects of light, photoperiod and feeding regimes. Aquaculture, 213: 151-161.

Guimarães-Cruz, R.J., Santos, J.E., Sato, Y. \& VelosoJúnior, V.C. 2009. Early development stages of the catfish Lophiosilurus alexandri Steindachner, 1877 (Pisces: Pseudopimelodidae) from the São Francisco River basin, Brazil. Journal of Applied Ichthyology, 25: 321-327.

Han, D., Xie, S.H., Lei, W., Zhu, X. \& Yang, Y. 2005. Effect of light intensity on growth, survival and skin color of juvenile Chinese longsnout catfish (Leiocassis longirostris Günther). Aquaculture, 248: 299-306.

Jauro, I.A. \& Usman, I. 2015. The effect of photoperiod on the growth of African catfish, (Clarias gariepinus Burchell, 1822) juveniles in the semi-arid zone of Nigeria. Nigerian Journal of Fisheries and Aquaculture, 3(1-2): 68-77.

Kitagawa, A.T., Costa, L.S., Paulino, R.R. \& Luz, R.K. 2015. Feeding behavior and the effect of photoperiod on the performance and hematological parameters of the pacamã catfish (Lophiosilurus alexandri). Applied Animal Behaviour Science, 1: 1-34.

Lima, L.C. \& Ribeiro, L.P. 2006. Effects of temperature on performance characteristics and the cortisol stress response of surubim Pseudoplatystoma sp. Journal of the World Aquaculture Society, 37(1): 89-95.

Marques, M.B.A., Moreira-Filho, O., Garcia, C. \& Margarido, V.P. 2008. Cytogenetic analyses of two endemic fish species from the São Francisco River basin: Conorhynchus conirostris and Lophiosilurus alexandri (Siluriformes). Genetics and Molecular Biology, 31: 215-221.

Mendonça, P.P., Ferreira, R.A., Vidal-Junior, M.V., Andrade, D.R., Santos, M.V.B., Ferreira, A.V. \& Rezende, R.P. 2009. Influence of photoperiod in the development of juveniles of tambaqui (Colossoma macropomum). Archiva Zootechnica, 58: 323-331.

Mizusawa, K., Kobayashi, Y., Sunuma, T., Asahida, T., Saito, Y. \& Takahashi, A. 2011. Inhibiting roles of melanin-concentrating hormone for skin pigment dispersion in barfin flounder, Verasper moseri. General and Comparative Endocrinology, 171: 75-81. doi: 10.1016/j.ygcen.2010.12.008

Received: 7 August 2018; Accepted: 15 December 2018
Mustapha, M.K, Okafor, B.U., Olaoti, K.S. \& Oyelakin, O.K. 2012. Effects of three different photoperiods on the growth and body coloration of juvenile African catfish, Clarias gariepinus (Burchell). Archives of Polish Fisheries, 20: 55-59. doi: 10.2478/v10086-0120007-1

Paiva-Ranzani, M.J.T. 2013. Methods for hematological analysis in fish. Eduem, Maringá.

Pedreira, M.M., Sampaio, E.V., Santos, J.C.E. \& Pires, A.V. 2012. Larviculture of two neotropical species with different distributions in the water column in light- and dark-colored tanks. Neotropical Ichthyology, 10: 439-444. doi: 10.1590/S1679-62252012005000 011

Pickering, A.D. 1993. Growth and stress in fish production. Aquaculture, 111: 51-63. doi: 10.1016/ 0044-8486(93)90024-S

Rodriguez, A., Castello-Orvay, F.E. \& Gisbert, E. 2009. Somatic growth, survival, feed utilization and starvation in European elver Anguilla anguilla (Linnaeus) under two different photoperiods. Aquaculture Research, 40: 551-557. doi: 10.1111/ j.1365-2109.2008.02129.x

Stefansson, S.O., Hansen, T. \& Taranger, G.L. 1993. Growth and parr-smolt transformation of Atlantic salmon (Salmo salar L.) under different light intensities and subsequent survival and growth in seawater. Aquacultural Engineering, 13: 231-242. doi: 10.1016/0144-8609(93)90014-3

Trippel, E.A. \& Neil, S.R.E. 2003. Effects of photoperiod and intensity on growth and activity of juvenile haddock (Melanogrammus aeglefinus) light. Aquaculture, 217: 633-645. doi: 10.1016/S0044-8486(02)00 198-9

Van Der Salm, A.L., Pavlidis, M. \& Flik, G. 2006. The acute stress response of red porgy, Pagrus pagrus, kept on a red or white background. General and Comparative Endocrinology, 145: 247-253. doi: 10.1016/ j.ygcen.2005.09.010

Vera, L.M., Cairns L., Sánchez-Vázquez, F.J. \& Migaud, H. 2009. Circadian rhythms of locomotor activity in the Nile tilapia (Oreochromis niloticus). Chronobiology International, 26: 666-681. doi: 10.1080/ 07420520902926017

Veras, G.C., Murgas, L.D.S., Zangeronimo, M.G., Oliveira, M.M., Rosa, P.V. \& Felizardo, V.O. 2013. Biological rhythms and photoperiod in fish. Archiva Zootechnica, 62: 25-43. 